\title{
Philippine Island Arc System Tectonic Features Inferred from Magnetic Data Analysis
}

\author{
Wen-Bin Doo ${ }^{1, *}$, Shu-Kun $\mathrm{Hsu}^{1,2}$, and Leo Armada ${ }^{2}$ \\ ${ }^{1}$ Center for Environmental Studies, National Central University, Taoyuan City, Taiwan, R.O.C. \\ ${ }^{2}$ Department of Earth Sciences, National Central University, Taoyuan City, Taiwan, R.O.C.
}

Received 18 February 2013, revised 22 November 2013, accepted 11 May 2015

\begin{abstract}
Running along the middle of the Philippine archipelago from south to north, the Philippine fault zone is one of the world's major strike-slip faults. Intense volcanism in the archipelago is attributed to the ongoing subduction along the trench systems surrounding it. This study interprets the magnetic data covering the Philippine fault zone and the bounding archipelago subduction systems to understand the structural characteristics of the study area. Magnetic data analysis suggests that the Philippine fault is roughly distributed along the boundary of high/low magnetization and separates the different amplitude features of the first order analytic signal. Visayas province is a specific area bounded by the other parts of the Philippine archipelago. Further differentiating the tectonic units, the proto-Southeast Bohol Trench should be the main tectonic boundary between Visayas and Mindanao. A clear NE - SW boundary separates Luzon from Visayas as shown by the variant depths to the top of the magnetic basement. This boundary could suggest the different tectonic characteristics of the two regions.
\end{abstract}

Key words: Philippine fault, Philippine archipelago, Magnetic data, Tectonic

Citation: Doo, W. B., S. K. Hsu, and L. Armada, 2015: Philippine island arc system tectonic features inferred from magnetic data analysis. Terr. Atmos. Ocean. Sci., 26, 679-686, doi: 10.3319/TAO.2015.05.11.04(TC)

\section{INTRODUCTION}

The Philippine archipelago resulted from late Mesozoic and Cenozoic poly-phase evolution involving subductions, collisions and strike-slip faulting. The archipelago consists mainly of accreted volcanic arcs, marginal basins, ophiolites, and continental fragments constituting the Philippine Mobile Belt (PMB) (Karig 1983; Mitchell et al. 1986; McCabe et al. 1987), on the western border of the Philippine Sea plate. This region is a complex portion of the tectonic boundary between the Eurasian Plate (Sunda Block), Indo-Australian and Philippine Sea Plate, comprising most of the Philippines. These tectonic plates have compressed and lifted parts of the Philippines causing extensive faulting, primarily on a N-S axis. The main fault, the Philippine fault zone, runs most of the length of the Philippines (Fig. 1). Overall, the free-air gravity anomaly is dominated by topography effects.

The Philippine fault zone is a system of active left-lateral strike-slip fault that stretches more than $1200 \mathrm{~km}$, throughout

\footnotetext{
* Corresponding author

E-mail:wenbindoo@gmail.com
}

the whole of the Philippine archipelago from southern Mindanao to northern Luzon (Fig. 1) (Allen 1962; Barrier et al. 1991). In spite of its recognition as a major geological structure and the location of destructive earthquakes, a number of characteristics such as fault location, slip rates, deformation and history are uncertain. In previous Philippine fault studies, Allen (1962) studied the geomorphic fault expression in the central Philippines and concluded it to be left-lateral, as did Rutland (1967). This conclusion was confirmed by Morante and Allen (1973). Since then, studies on the Philippine fault have been proposed using various approaches (e.g., Cardwell et al. 1980; Lewis et al. 1982; Karig 1983; Wolfe 1983; Barcelona 1986). Bischke et al. (1990) used aeromagnetic data to interpret the Philippine fault system and identified a major, previously unrecognized, branch of the Philippine fault, named the Sibuyan Sea branch. However, in their studies, they did not apply other analytical methods to interpret the magnetic data. In this study we present several analytical techniques to examine the magnetic data and discuss the features in the Philippine fault zone and the general Philippine island arc system tectonic characteristics. 


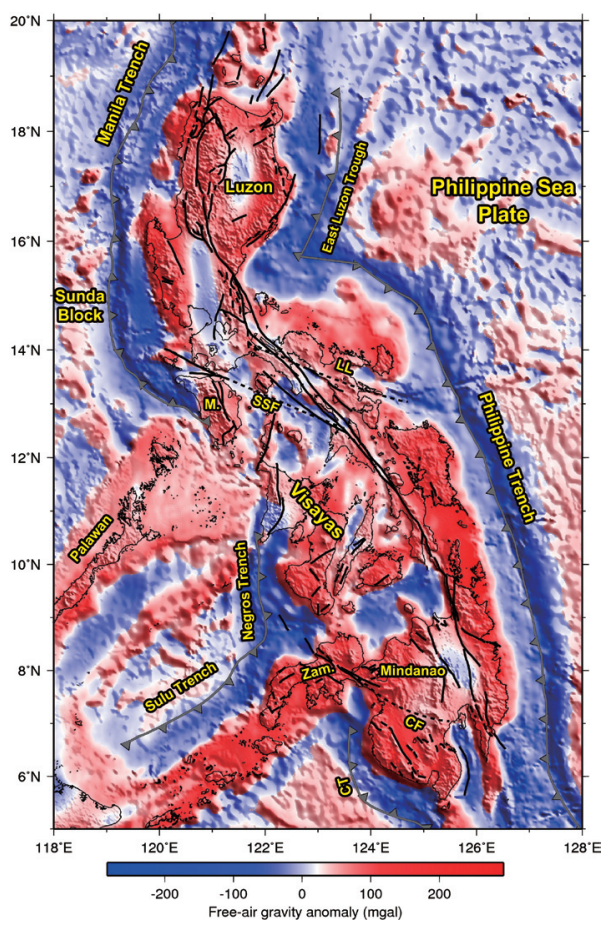

Fig. 1. Free-air gravity anomaly map in the Philippines. Black lines indicate the Philippine fault system. CF: Cotabato Fault; CT: Cotabato Trench; LL: Legaspi Lineament; M: Mindoro; SSF: Sibuyan Sea Fault; Zam: Zamboanga Peninsula.

\section{TECTONIC SETTING OF THE PHILIPPINES}

The Philippine archipelago is bounded to the east and west by subduction zones (Fig. 1). West of the archipelago are the east-dipping subduction zones along the Manila Trench, Negros Trench, Sulu Trench, and the Cotabato Trench, which accommodate deformation due to the subducting Sunda Plate beneath the PMB (Lewis and Hayes 1984; Stephan et al. 1986; Rangin 1989). On the eastern boundary of the archipelago, the Philippine Sea Plate, through oblique subduction, is being consumed along the Philippine Trench and East Luzon Trough (Cardwell et al. 1980; Hamburger et al. 1983) connected by an E NE trending transcurrent fault. The East Luzon Trough is a young feature, defined by a shallow Benioff zone and lacks any associated volcanism (Hamburger et al. 1983; Bautista et al. 2001). These subduction zones together with the collision zones in Taiwan, Mindoro, Panay and Mindanao islands form a contiguous complex boundary between the colliding Eurasian Plate and the Philippine Sea Plate.

Gervasio (1967) first defined the PMB, a zone of intense deformation and active seismicity between convergent zones bounding the Philippine Archipelago, to include North Luzon, South Luzon, West Visayas, East Visayas, Northwest Mindanao, Zamboanga, Cotabato, and the rest of Mindanao with Catanduanes Island. However, Lagmay et al. (2009) suggested that the motion of the Philippine Sea
Plate at the eastern margin of Luzon is mainly decoupled along the left-lateral Polilio-Philippine fault zone. They consider the eastern section of North Luzon as part of the Philippine Sea Plate and proposed that the Philippine fault has major implications on the plate boundary delineation in the Philippines. Queano et al. (2007) stated that based on the convergence rate $\left(8 \mathrm{~cm} \mathrm{yr}^{-1}\right)$, the Wadati-Benioff zone depth $(<200 \mathrm{~km})$, the age of volcanic rocks, the East Luzon Trench is widely believed to have been initiated $3-5 \mathrm{Ma}$ (Karig 1975; Cardwell et al. 1980; Hamburger et al. 1983; Ozawa et al. 2004). This implies that prior to the Pliocene, parts of the Philippine archipelago, including north Luzon, formed part of the Philippine Sea Plate.

The Philippine fault resulted from oblique convergence between the Philippine Sea Plate and Sunda Block/ Eurasian Plate that started during the Middle Miocene (Aurelio et al. 1991) and is propagating southward, following a simple curved trace in the central and southern Philippines. All faults in the Philippines are inter-related by the causative PMB tectonic forces or tectonic induced volcanism. In northern Luzon the fault has become braided and is no longer single. Several subordinate faults are intimately linked to the evolution of the Philippine fault zone. The Legaspi Lineament is seismically active and is a left-lateral fault, acting as a transfer fault connecting the Philippine Fault Zone and the Philippine Trench. An offshore extension of the Philippine fault zone in the central Philippines is the left-lateral Sibuyan Sea Fault. After collision with the Palawan-Mindoro continental block, continued motion along the Manila trench north of Mindoro has ruptured the central Philippines along the Sibuyan Sea fault branch of the Philippine fault (Bischke et al. 1990). Mindanao presents another left-lateral fault, the NW - SE trending Sindangan-Cotabato-Daguma Lineament (also called Cotabato Fault), the northern extension of which connects with the Siayan-Sindangan Suture Zone (Yumul et al. 2008).

\section{MAGNETIC DATA ANALYSIS AND INTERPRETATION}

Magnetic data generally provide fundamental information about the geological structural characteristics and the volcanic nature of underlying sources, particularly the depths and geometries of magnetic sources. Doo et al. (2015) compiled magnetic data including land, marine and aeromagnetic data to obtain a new magnetic anomaly map of East Asia. This dataset covers the Philippine fault zone and the bounding archipelago subduction systems (Fig. 2). A new magnetic dataset is processed in this study with different data reduction and inversion techniques, such as magnetic inversion, analytic signal and spectrum analysis. Based on the results from the new dataset, magnetic signature interpretations of the various tectonic elements are inferred for the Philippine tectonic setting. 


\subsection{Geomagnetic Characteristics of the Philippine Island Arc System}

To understand the geomagnetic characteristics of the Philippine Island arc system, we conducted a magnetization inversion using the magnetic anomalies of Doo et al. (2015). A $10 \times 10 \mathrm{~km}$ magnetic anomaly grid spacing is adopted in this work. Furthermore, we assume that the magnetic anomalies are attributed to an equivalent layer with a constant thickness of $5 \mathrm{~km}$ and the top of each block is the seafloor. The corresponding bathymetry is gridded at the same spacing as the magnetic data. The magnetization direction is presumed to be the same as the present-day geomagnetic field (inclination of $23.1^{\circ}$ and declination of $-2.3^{\circ}$ ). The resulting magnetization pattern is similar to the gravity anomaly map, except for the regions adjacent to Palawan and the central Philippines (Visayas province). In the Philippine archipelago positive magnetization is distributed mainly along the islands of Luzon, Samar, Leyte, and the south portion of Mindanao. These locations are similar to the magmatic arcs identified by Yumul et al. (2008). Visayas Province is a specific area with high free-air gravity anomaly but low magnetization. This phenomenon indicates different composition and/or tectonic characteristics in comparison with other parts of the Philippine archipelago.

The inversion result shows the main Philippine fault is

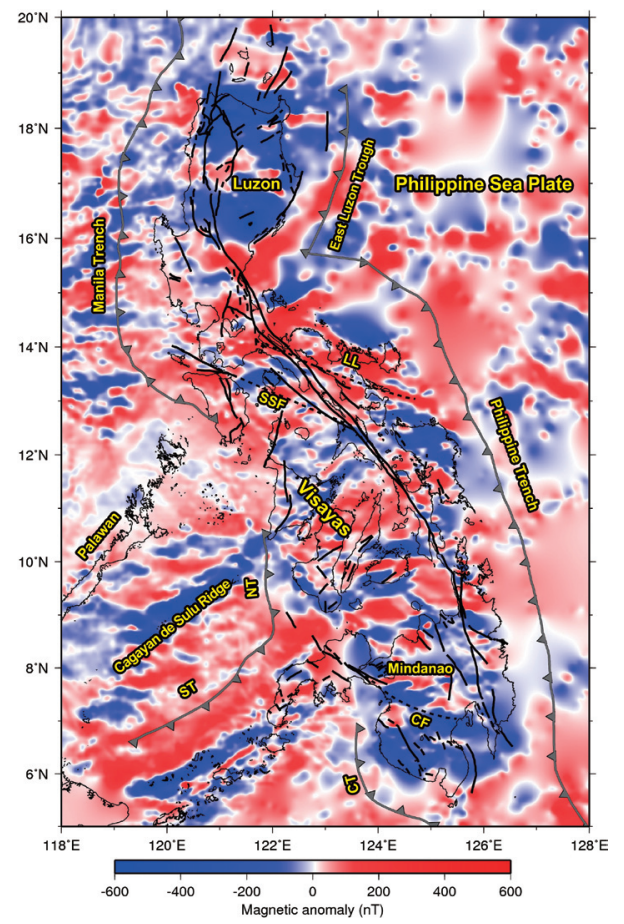

Fig. 2. Magnetic anomaly map in the Philippines. Black lines indicate the Philippine fault system. CF: Cotabato Fault; CT: Cotabato Trench; LL: Legaspi Lineament; NT: Negros Trench; SSF: Sibuyan Sea Fault; ST: Sulu Trench. located roughly along the boundary between high and low magnetization (Fig. 3). This result also illustrated that strains are easily induced at the boundary due to the different compositions. Another significant feature is the NE - SW trending high magnetization zone distributed along the Cagayan de Sulu Ridge (Fig. 3) and is extended to Masbate (west side of the Philippine fault). However, it shows less continuous south of Panay. Bellon and Rangin (1991) proposed that the Cagayan de Sulu Ridge is colliding with the southern part of Panay based on the dacite and andesite from the Cagayan de Sulu Ridge that had been accreted and emplaced onland in southern Panay. This is evidence of the subducted Cagayan de Sulu Ridge. The original magnetic lineations trend in the Sulu Sea is NE - SW (Yumul et al. 2000) which indicates the spreading trend. This NE - SW spreading axis is consistent with the general tectonic trend in this part of the island arc system. In central Visayas the NE - SW trend of the high magnetization is obvious. This signal may result from the subducted portion of the Cagayan de Sulu Ridge.

\subsection{Tectonic Boundaries in the Philippine Archipelago}

The analytical signal technique has been widely used to outline geological boundaries such as faults or contacts (e.g., Nabighian 1972, 1974, 1984; Roest et al. 1992; Hsu et al. 1996, 1998; Debeglia and Corpel

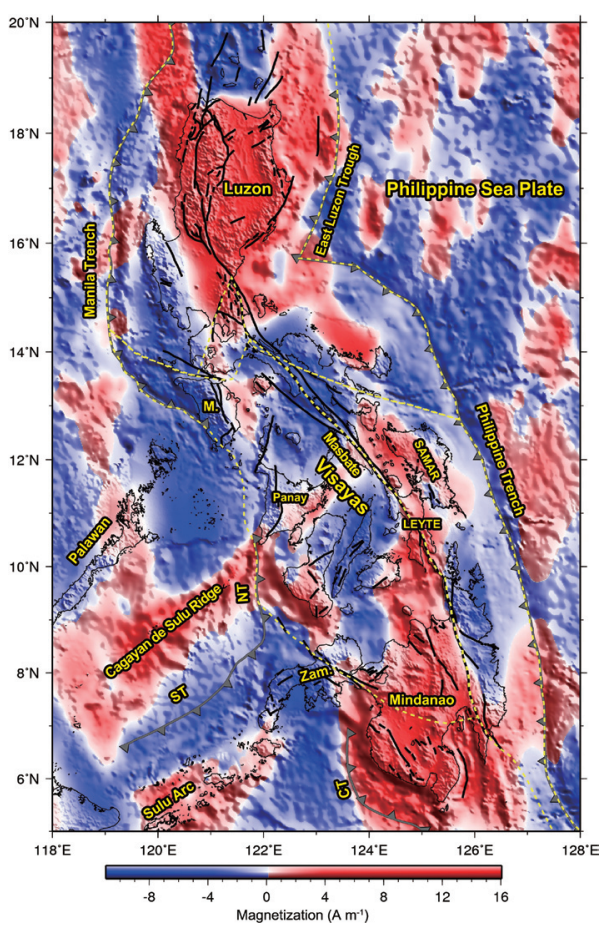

Fig. 3 Equivalent magnetization distribution for the magnetic data shown in Fig. 2. Black lines indicate the Philippine fault system, yellow dashed lines indicate tectonic boundaries identified by Rangin et al. (1999). CT: Cotabato Trench; M: Mindoro; NT: Negros Trench; ST: Sulu Trench; Zam: Zamboanga Peninsula. 
1997; Hsu 2002; Doo et al. 2007, 2009, 2011). Hsu et al. (1996) proposed that for 3-D potential-field anomalies, the nth-order enhanced analytic signal can be defined as: $A_{n}(x, y)=\frac{\partial}{\partial x}\left(\frac{\partial^{n} G}{\partial z^{n}}\right) \hat{x}+\frac{\partial}{\partial y}\left(\frac{\partial^{n} G}{\partial z^{n}}\right) \hat{y}+i \frac{\partial}{\partial z}\left(\frac{\partial^{n} G}{\partial z^{n}}\right) \hat{z}$, and its amplitude as: $\left|A_{n}(x, y)\right|=\sqrt{\left(\nabla^{n} G_{x}\right)^{2}+\left(\nabla^{n} G_{y}\right)^{2}+\left(\nabla^{n} G_{z}\right)^{2}}$, where $G$ is the potential-field anomaly, $G_{x}=\partial G / \partial x$, $G_{y}=\partial G / \partial y$, and $G_{z}=\partial G / \partial z, \nabla^{n}=\partial^{n} / \partial z^{n}$. The geological boundary outlines can be determined by tracing the maximum amplitudes of an enhanced analytic signal composed of the nth-order vertical derivative values of two horizontal and one vertical gradient. This technique has the advantage of avoiding dependence on the ambient potential field and aiding potential-field anomaly quantitative interpretation. The improved resolution allows us to better detect the geological boundaries of causative sources. However, this method is very sensitive to noise and could easily cause errors in the amplitude calculation, as taking the derivative too many times can increase the noise. Consequently, we used only the amplitude of the first-order analytical signal (AAS) to determine the location of the structural boundaries. The estimation results are shown in Fig. 4a. The maximum in the analytical signal amplitude indicates magnetic contrast positions. A simple method for the automatically detecting these maximums is based on Blakely and Simpson's (1986) approach. In this study we select the index $\mathrm{N}=3$ to represent the structural boundary locations. Most of the circles are located in the positive magnetization areas (Fig. 4b).

In Fig. 4b, except in the Philippine archipelago, high AAS (yellow circles) cluster in the South China Sea (old spreading center), Sulu Sea (Cagayan de Sulu Ridge), Sulu Arc (volcanic arc), and east side of the East Luzon Trough (could be the boundary between Benham Rise and Philippines). This result demonstrates that the tools (magnetic data collocated using the analytical signal method) are useful to identify the structural boundaries. In the northern part (Luzon), the Philippine fault corresponds to a complex braided system of left-lateral strike-slip faults. The NW oriented main active branch splits into an array of north striking splays and plays an important role in the tectonic evolution of the region. Most high AAS distributions are consistent with the fault locations and some are located in the Cagayan Valley Basin (CVB). The reason could be because the basin fill is comprised of volcanic-epiclastic and clastic sediments (Caagusan 1977), resulting in large magnetic contrasts. In the central part of the Philippines, the high AAS distributions reveal various features at both sides of the Philippine fault. This illustrates that the Philippine fault is a significant boundary in this region. Between the Philippine fault and (a)

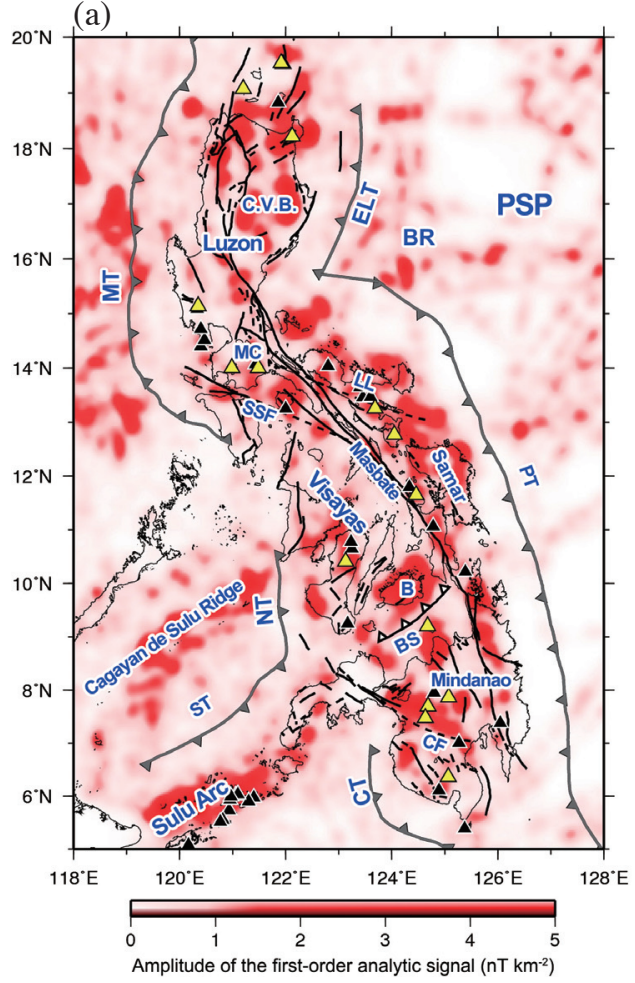

(b)

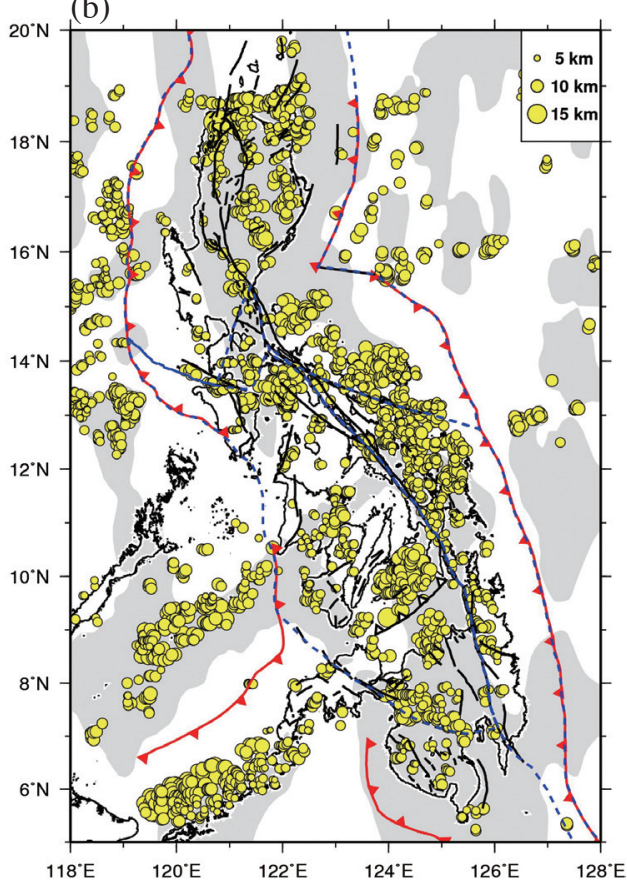

Fig. 4. (a) Amplitude of the first-order of analytic signal results. Triangles indicate volcano, triangle with yellow color indicate active volcanoes. B: Bohol; BR: Benham Rise; BS: Bohol Sea; CF: Cotabato Fault; CT: Cotabato Trench; CVB: Cagayan Valley Basin; LL: Legaspi Lineament; MC: Macolod Corridor; MT: Manila Trench; NT: Negros Trench; PSP: Philippine Sea Plate; PT: Philippine Trench; SSF: Sibuyan Sea Fault; ST: Sulu Trench. (b) Yellow circles indicate the maximum value of Amplitude of the first-order of analytic signal. Gray areas indicate the positive magnetization areas. Blue dashed lines indicate the major tectonic boundaries identified from Rangin et al. (1999); black lines indicate the Philippine fault system; line with open triangles corresponds to the proto-Southeast Bohol Trench. 
Philippine Trench, high AAS values are distributed roughly following the trend of the islands and faults. The volcano distribution also follows this trend. In addition, the active volcano locations are also accompanied by high analytic signal amplitudes. In this region the Legaspi Lineament, a NW - SE structure merging with the main Philippine fault extends to the Philippine Trench, forming a tectonic boundary (Rangin et al. 1999). This boundary is seismically active (Le Rouzic and Gaulon 1997) and coincident with concentrated high AAS. High magnetic signal responses are observed at Samar Island, due to the main Cenozoic volcanic rocks covering the area. On the other hand, on the west side of the Philippine fault, a branch of the Philippine fault, named the Sibuyan Sea fault separates Luzon and Visayas. In western Visayas province (between Negros Trench and Philippine fault), the high AAS distribution trend is NE - SW. Furthermore, the fault distribution and geometry of the islands also roughly follow this trend. This phenomenon is quite different compared with other areas in the Philippines. Rangin et al. (1999) proposed that the southern tectonic boundary of the Visayas block is the Cotabato Fault, a left-lateral fault in Mindanao that extends from the Negros Trench (Pubellier et al. 1996). In our analysis (Fig. 4) concentrated high amplitude values indeed occur along the Cotabato Fault. However, the high AAS and fault distribution trend still reveal a NW - SE trend in north Mindanao and this extends to the Bohol Sea. The trend changes to NE - SW north of Bohol Island. A NE - SW trending low gravity anomaly was observed between Central Visayas and Mindanao in a previous study. This feature is believed to represent an ancient trench southeast of Bohol Island (Yumul et al. 2000). In addition, this feature is located between two different high AAS value distribution trends. Therefore, we suggest that the southern boundary of Visayas block could be the proto-trench (protoSoutheast Bohol Trench) not including north Mindanao. The high AAS distribution characteristic also illustrates that the Visayas province could be another tectonic unit. As we mentioned above, the Cagayan de Sulu Ridge could extend to Masbate (Fig. 3). In Fig. 4 the high amplitude value distributions also reveal NE - SW trending in the same area.

\subsection{Thickness of Magnetic Sources and the Volcano Distribution}

As mentioned previously, the study area has a complex tectonic setting. The Philippine archipelago is cut by the Philippine fault, a left-lateral strike-slip fault, and bounded by two subduction zone systems. Is there any variation in magnetic basement depths in Philippine area? Magnetic anomalies can offer good insights into deep crustal structures and physical properties of the Earth, particularly at depth, magnetization and the geometries of magnetic sources. There is an intimate connection between surface magnetic anomalies and the Earth's geothermal field, since rock magnetization can be strongly affected by temperature variations. The depth of magnetic sources can be estimated by spectrum analysis. If the basement rocks are magnetized, the top of the calculated magnetic sources might correspond to the geological basement, and the base of the magnetic sources is assumed to be at the Curie point depth. At temperatures greater than the Curie point, rocks are paramagnetic. Based on this assumption, Tanaka et al. (1999) developed a method, which allows calculating the depths of the top and centroid of the magnetic sources by fitting a straight line through the high and low wave number portions of the power spectrum.

We used a window size equal to $150 \times 150 \mathrm{~km}$ for the spectrum calculation in this study. The calculation results, depths of the top $\left(Z_{t}\right)$ and base $\left(Z_{b}\right)$ of the magnetic basement are shown in Figs. 5a and b, respectively. In the Philippines, $Z_{t}$ can roughly be divided into two parts by a sharp boundary trending NE - SW located around $14^{\circ} \mathrm{N}$ (green dashed line shown in Fig. 5a). Barrier et al. (1991) proposed that the Philippine archipelago is not entirely a part of Eurasia, but also belongs in part to an independent block. From their kinematic analysis, in the central and southern Philippines, the parameters are in good agreement with field and geophysical data. The northern Philippines belong to another block. Rangin et al. (1999) proposed that the Verde Passage Fault (part of Sibuyan Sea Fault) and the Macolod Corridor separate the Luzon block to the north from a Visayas block to the south. Figure 5a shows the location of this NE - SW trending boundary seems consistent with these studies. The Philippine Trench extends from the Island of Mindanao in the south to its northern termination, east of Central Luzon, and the Manila Trench extends southward from Taiwan in the north to Mindoro Island in the south along the western margin of Luzon. The interesting thing is that the termination points of these two trenches are similar to the boundary we identified in Fig. 5a. West of the Philippines the active zone consists of subduction and collision. This type of interaction changed in Mindoro. On the east side, a rough E W trending transform fault connects the East Luzon Trough and Philippine Trench, indicating a transition zone. Therefore, we suggest that this boundary could be related to a different stress interaction on both sides of the Philippines.

The pattern of $Z_{b}$ (Fig. $5 \mathrm{~b}$ ) is similar to the pattern of the magnetic basement thickness (Fig. 5c). Most parts of the Philippine fault follow the small $Z_{b}$ values trend in the Philippines. Heat flow values and crustal thickness present the following correlation: $Q=k\left[\left(T_{\text {Curie }}-T_{\text {sufface }}\right) /\left(Z_{b}-Z_{t}\right)\right]$, where $Q$ is the heat flow $\left(\mathrm{mw} \mathrm{m}^{-2}\right), k$ is the thermal conductivity ( $\left.\mathrm{W} \mathrm{mk}^{-1}\right), T_{\text {Curie }}$ and $T_{\text {surface }}$ indicate the temperatures at the base and top of the crust. If we assume that the crustal thermal conductivity is constant, then the magnetic basement thickness can reflect heat flow directly. In general cases the thinner the magnetic basement, the higher the heat flow value. In Fig. 5c most of the volcanoes (especially the active volcanoes) are located in a thin magnetic basement 
(a)

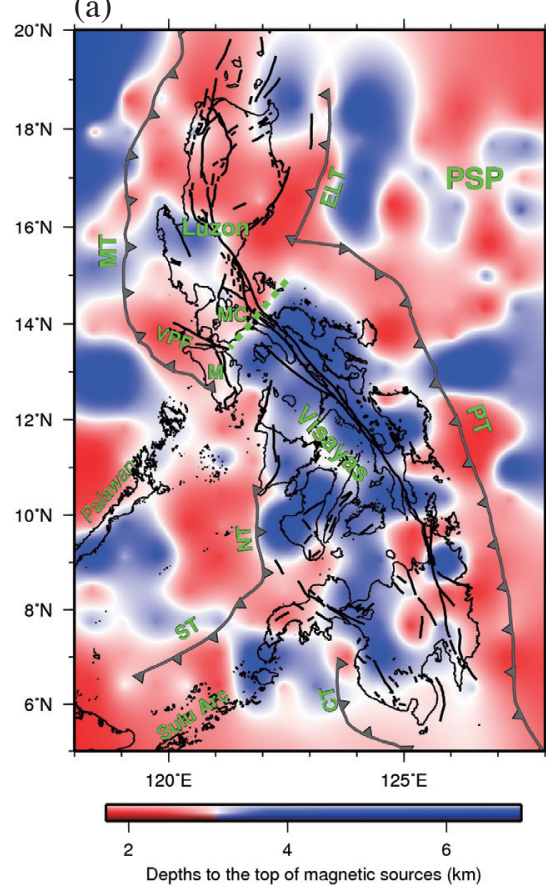

(b)

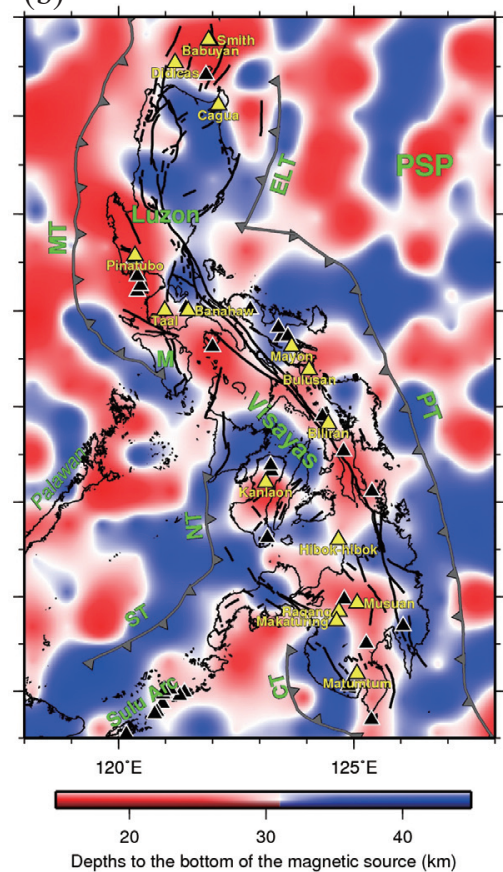

(c)

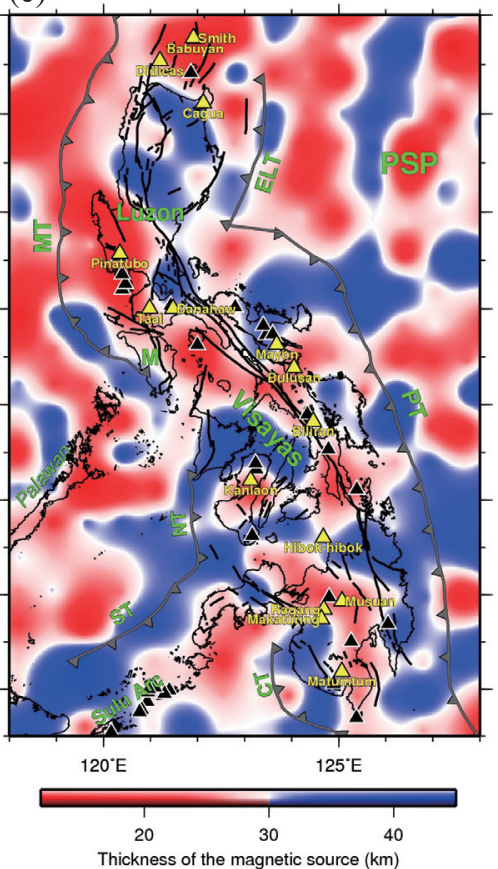

Fig. 5. (a) Depth to the top of the magnetic basement distribution map. (b) Depth to the base of the magnetic basement distribution map. (c) Thickness of the magnetic basement distribution map. Triangles indicate volcanoes; triangles with yellow color indicate active volcanoes. Black lines indicate the Philippine fault system. CF: Cotabato Fault; CT: Cotabato Trench; ELT: East Luzon Trough; M: Mindoro; MC: Macolod Corridor; MT: Manila Trench; NT: Negros Trench; PSP: Philippine Sea Plate; PT: Philippine Trench; ST: Sulu Trench.

thickness area. In the vicinity of the Macolod Corridor, high volcanic activity is observed where crustal thinning and spreading occurs. Thus, the calculation results seem consistent with the volcano distributions.

\section{CONCLUSION}

Based on magnetic data analysis, the main conclusions in this study are:

(1) The positive magnetization distribution coincides closely with the magmatic arcs related to subduction identified by Yumul et al. (2008). The Philippine fault occurs roughly along the boundary of high/low magnetization. The NE - SW trending high magnetization located at Central Visayas may indicate that the NE portion of the Cagayan de Sulu Ridge is already subducted beneath the Negros Trench.

(2) In the central Philippines the Philippine fault separates different amplitude features of the first-order analytical signal (Fig. 4). This result suggests that the Philippine fault displays a main boundary in the central Philippines. Based on the high amplitude values we suggest that the proto-Southeast Bohol Trench could be the major tectonic boundary between the Visayas block and Mindanao instead of the Cotabato Fault. Both the magnetic inversion and 3-D analytical signal results illustrate that Visayas Province could be another tectonic unit distinct from other parts of the Philippine archipelago.

(3) A NE - SW trending boundary separating the Luzon block to the north from a Visayas block to the south in the depth to the magnetic basement top is observed. The trace of this boundary links the subduction and collision transition point (Mindoro) in the west and the transform fault (connecting the East Luzon Trough and the Philippine Trench) east of the Philippine archipelago.

Acknowledgements We thank J. Y. Lin for her helpful discussion and comments. Comments from the two Anonymous Reviewers helped to significantly improve this manuscript. This study was supported under a grant of the Ministry of Science and Technology of Taiwan.

\section{REFERENCES}

Allen, C. R., 1962: Circum-Pacific faulting in the Philippines-Taiwan region. J. Geophys. Res., 67, 4795-4812, doi: 10.1029/JZ067i012p04795. [Link]

Aurelio, M. A., E. Barrier, C. Rangin, and C. Müller, 1991: The Philippine Fault in the Late Cenozoic tectonic evolution of the Bondoc-Masbate-N. Leyte area, Central Philippines. J. Southeast Asian Earth Sci., 6, 221-238, doi: 10.1016/0743-9547(91)90069-A. [Link]

Barcelona, B. M., 1986: The Philippine fault and its tectonic significance. Mem. Geol. Soc. China, 7, 34-44. 
Barrier, E., P. Huchon, and M. Aurelio, 1991: Philippine fault: A key for Philippine kinematics. Geology, 19, 3235, doi: 10.1130/0091-7613(1991)019<0032:PFAK$\mathrm{FP}>2.3 . \mathrm{CO} ; 2$. [Link]

Bautista, B. C., M. L. P. Bautista, K. Oike, F. T. Wu, and R. S. Punongbayan, 2001: A new insight on the geometry of subducting slabs in northern Luzon, Philippines. Tectonophysics, 339, 279-310, doi: 10.1016/S00401951(01)00120-2. [Link]

Bellon, H. and C. Rangin, 1991: Geochemistry and isotopic dating of Cenozoic volcanic arc sequences around the Celebes and Sulu seas. In: Silver, E. A., C. Rangin, M. T. von Breymann (Eds.), Proceedings of the Ocean Drilling Program, Scientific Results, Vol. 124, 321-338.

Bischke, R. E., J. Suppe, and R. del Pilar, 1990: A new branch of the Philippine fault system as observed from aeromagnetic and seismic data. Tectonophysics, 183, 243-264, doi: 10.1016/0040-1951(90)90419-9. [Link]

Blakely, R. J. and R. W. Simpson, 1986: Approximating edges of source bodies from magnetic or gravity anomalies. Geophysics, 51, 1494-1498, doi: 10.1190/1.1442197. [Link]

Caagusan, N. L., 1977: Source material, compaction history and hydrocarbon occurrence in the Cagayan Valley basin, Luzon, Philippines. SEAPEX Program, Offshore Southeast Asia Conference, Southeast Asia Pet. Explor. Soc., Singapore.

Cardwell, R. K., B. L. Isaacks, and D. E. Karig, 1980: The spatial distribution of earthquakes, focal mechanism solutions, and subducted lithosphere in the Philippine and northeastern Indonesian Islands. In: Hayes, D. E. (Ed.), The Tectonic and Geologic Evolution of Southeast Asian Seas and Islands, American Geophysical Union, Washington, D. C., doi: 10.1029/GM023p0001. [Link]

Debeglia, N. and J. Corpel, 1997: Automatic 3-D interpretation of potential field data using analytic signal derivatives. Geophysics, 62, 87-96, doi: 10.1190/1.1444149. [Link]

Doo, W. B., S. K. Hsu, and Y. C. Yeh, 2007: A derivativebased interpretation approach to estimating source parameters of simple 2D magnetic sources from Euler deconvolution, the analytic-signal method and analytical expressions of the anomalies. Geophys. Prospect., 55, 255-264, doi: 10.1111/j.1365-2478.2007.00603.x. [Link]

Doo, W. B., S. K. Hsu, C. H. Tsai, and Y. S. Huang, 2009: Using analytic signal to determine magnetization/density ratios of geological structures. Geophys. J. Int., 179, 112-124, doi: 10.1111/j.1365-246X.2009.04297.x. [Link]

Doo, W. B., S. K. Hsu, C. C. Chen, H. H. Hsieh, H. Y. Yen, Y. G. Chen, and W. Y. Chang, 2011: Magnetic signature of Siaolin Village, southern Taiwan, after burial by a catastrophic landslide due to Typhoon Morakot. Nat.
Hazards Earth Syst. Sci., 11, 759-764, doi: 10.5194/ nhess-11-759-2011. [Link]

Doo, W. B., S. K. Hsu, and L. Armada, 2015: New magnetic anomaly map of the East Asia with some preliminary tectonic interpretations. Terr. Atmos. Ocean. Sci., 26, 73-81, doi: 10.3319/TAO.2014.08.19.07(GRT). [Link]

Gervasio, F. C., 1967: Age and nature of orogenesis of the Philippines. Tectonophysics, 4, 379-402, doi: 10.1016/0040-1951(67)90006-6. [Link]

Hamburger, M. W., R. K. Cardwell, and B. L. Isacks, 1983: Seismotectonics of the northern Philippine island arc. In: Hayes, D. E. (Ed.), The Tectonic and Geologic Evolution of Southeast Asian Seas and Islands: Part 2, American Geophysical Union, Washington, D. C., doi: 10.1029/GM027p0001. [Link]

Hsu, S. K., 2002: Imaging magnetic sources using Euler's equation. Geophys. Prospect., 50, 15-25, doi: 10.1046/j.1365-2478.2001.00282.x. [Link]

Hsu, S. K., J. C. Sibuet, and C. T. Shyu, 1996: High-resolution detection of geologic boundaries from potential-field anomalies: An enhanced analytic signal technique. Geophysics, 61, 373-386, doi: 10.1190/1.1443966. [Link]

Hsu, S. K., D. Coppens, and C. T. Shyu, 1998: Depth to magnetic source using the generalized analytic signal. Geophysics, 63, 1947-1957, doi: 10.1190/1.1444488. [Link]

Karig, D. E., 1975: Basin genesis in the Philippine Sea. DSDP Init. Rep., 31, 857-879.

Karig, D. E., 1983: Accreted terranes in the northern part of the Philippine archipelago. Tectonics, 2, 211-236, doi: 10.1029/TC002i002p00211. [Link]

Lagmay, A., L. G. Tejada, R. E. Pena, M. Aurelio, B. Davy, S. David, and E. Billedo, 2009: New definition of Philippine Plate boundaries and implications to the Philippine Mobile Belt. J. Geol. Soc. Philipp., 64, 17-30.

Le Rouzic, S. and R. Gaulon, 1997: Seismotectonic analysis of the lineament of Legaspi, (Philippines); seismic crisis of 1995-96. Eos, Trans., AGU, 78, 718.

Lewis, S. D. and D. E. Hayes, 1984: A geophysical study of the Manila Trench, Luzon, Philippines: 2. Fore arc basin structural and stratigraphic evolution. J. Geophys. Res., 89, 9196-9214, doi: 10.1029/JB089iB11p09196. [Link]

Lewis, S. D., D. E. Hayes, and C. L. Mrozowski, 1982: The origin of the west Philippine basin by inter-arc spreading. In: Balce, G. R. and A. S. Zanoria (Eds.), Geology and Tectonics of the Luzon-Marianas Region, Proceedings of the CCOP-IOC SEATAR Workshop, Manila, Philippines, 31-52.

McCabe, R., E. Kikawa, J. T. Cole, A. J. Malicse, P. E. Baldauf, J. Yumul, and J. Almasco, 1987: Paleomagnetic results from Luzon and the central Philippines. J. Geophys. Res., 92, 555-580, doi: 10.1029/ JB092iB01p00555. [Link] 
Mitchell, A. G. H., F. Hernandez, and A. P. dela Cruz, 1986: Cenozoic evolution of the Philippine archipelago. $J$. Southeast Asian Earth Sci., 1, 3-22, doi: 10.1016/07439547(86)90003-6. [Link]

Morante, E. M. and C. R. Allen, 1973: Displacement on the Philippine fault during the Ragay Gulf earthquake of 17 March 1973. Abstr. Programs Geol. Soc. Am., 5, 744-745.

Nabighian, M. N., 1972: The analytic signal of two-dimensional magnetic bodies with polygonal cross-section: Its properties and use for automated anomaly interpretation. Geophysics, 37,507-517, doi: 10.1190/1.1440276. [Link]

Nabighian, M. N., 1974: Additional comments on the analytic signal of two-dimensional magnetic bodies with polygonal cross-section. Geophysics, 39, 85-92, doi: 10.1190/1.1440416. [Link]

Nabighian, M. N., 1984: Toward a three-dimensional automatic interpretation of potential field data via generalized Hilbert transforms: Fundamental relations. Geophysics, 49, 780-786, doi: 10.1190/1.1441706. [Link]

Ozawa, A., T. Tagami, E. L. Listanco, C. B. Arpa, and M. Sudo, 2004: Initiation and propagation of subduction along the Philippine Trench: Evidence from the temporal and spatial distribution of volcanoes. J. Asian Earth Sci.,23,105-111, doi: 10.1016/S1367-9120(03)00112-3. [Link]

Pubellier, M., R. Quebral, M. Aurelio, and C. Rangin, 1996: Docking and post-docking escape tectonics in the southern Philippines. Spec. Publ. Geol.Soc. Lond., 106, 511-523, doi: 10.1144/GSL.SP.1996.106.01.32. [Link]

Queano, K. L., J. R. Ali, J. Milsom, J. C. Aitchison, and M. Pubellier, 2007: North Luzon and the Philippine Sea plate motion model: Insights following paleomagnetic, structural, and age-dating investigations. J. Geophys. Res., 112, B05101, doi: 10.1029/2006JB004506. [Link]
Rangin, C., 1989: The Sulu Sea, a back-arc basin setting within a Neogene collision zone. Tectonophysics, 161, 119-141, doi: 10.1016/0040-1951(89)90307-7. [Link]

Rangin, C., X. Le Pichon, S. Mazzotti, M. Pubellier, N. Chamot-Rooke, M. Aurelio, A. Walpersdorf, and R. Quebral, 1999: Plate convergence measured by GPS across the Sundaland/Philippine Sea Plate deformed boundary: the Philippines and eastern Indonesia. Geophys. J. Int., 139, 296-316, doi: 10.1046/j.1365246x.1999.00969.x. [Link]

Roest, W. R., J. Verhoef, and M. Pilkington, 1992: Magnetic interpretation using the 3-D analytic signal. Geophysics, 57, 116-125, doi: 10.1190/1.1443174. [Link]

Rutland, R. W. R., 1967: A tectonic study of part of the Philippine fault zone. Q.J. Geol. Soc. Lond., 123, 293325, doi: 10.1144/gsjgs.123.1.0293. [Link]

Stephan, J. F., R. Blanchet, C. Rangin, B. Pelletier, J. Letouzey, and C. Muller, 1986: Geodynamic evolution of the Taiwan-Luzon-Mindoro belt since the late eocene. Tectonophysics, 125, 245-268, doi: 10.1016/0040-1951(86)90017-X. [Link]

Tanaka, A., Y. Okubo, and O. Matsubayashi, 1999: Curie point depth based on spectrum analysis of the magnetic anomaly data in East and Southeast Asia. Tectonophysics, 306, 461-470, doi: 10.1016/S0040-1951(99)000724. [Link]

Wolfe, J. A., 1983: Origin of the Philippines by accumulation of allochthons. Philipp. Geol., 37, 17-33.

Yumul, G. P., Jr., C. B. Dimalanta, R. A. Tamayo Jr., and J. A. L. Barretto, 2000: Contrasting morphological trends of islands in Central Philippines: Speculation on their origin. Isl. Arc, 9, 627-637, doi: 10.1111/j.14401738.2000.00307.x. [Link]

Yumul, G. P., Jr., C. B. Dimalanta, V. B. Maglambayan, and E. J. Marquez, 2008: Tectonic setting of a composite terrane: A review of the Philippine island arc system. Geosci.J., 12, 7-17, doi: 10.1007/s12303-0080002-0. [Link] 